\title{
The Effect of Project Exhibition Event on Physics Success and Prospective Teachers' Opinions about Projects
}

\author{
Ezgi Güven Yıldırım*, Ayşe Nesibe Köklükaya \\ Department of Science Education, Gazi University, Gazi Faculty of Education, Ankara, Turkey \\ *Corresponding Author: ezgiguven@gazi.edu.tr
}

\section{ABSTRACT}

The purposes of this study were first to investigate the effects of the project-based learning (PBL) method and project exhibition event on the success of physics teacher candidates, and second, to reveal the experiment group students' views toward this learning method and project exhibition. The research model called explanatory mixed method, in which both quantitative and qualitative research methods were used. The findings obtained from the research show that there was a significant difference in favor of the experiment group among the point averages of the achievement post-test of the groups. When the findings regarding the questions posed to prospective teachers were examined, it was seen that while they stated that there were a few disadvantages of PBL and project exhibition event, there were many advantages. The results obtained from the quantitative and qualitative data of the research showed that PBL contributed positively to the teaching process and learning characteristics in many aspects.

KEY WORDS: project-based learning method; project exhibition event; prospective teachers; success; physics

\section{INTRODUCTION}

T he aim of science education is to teach students to reach the knowledge and use that knowledge so that they can develop a scientific understanding and grow up as literate individuals in science (Gücüm, 1998). As such, science education should provide individuals with the knowledge, ability, attitude, and behavior required in real-life so that they can use these skills and abilities in a way that will enhance their lives (Cansüngü, 2000). The education and training of science play an extremely important role in the growth of individuals to be able to argue, search, question, try, observe, be creative, think critically, produce scientific solutions to problems, and develop scientific attitudes (Ayas et al., 2002). The growth of individuals possessing these characteristics is only possible by appropriately structuring the education system. The education system should enable the student to be responsible for his/her own learning, to obtain the knowledge, and to apply that knowledge in his/her daily life, and this structure should be supplied by suitable education methods and techniques.

While science courses are part of the education system in Turkey, the teaching methods and techniques used most often require the student to be a passive recipient, and as a result, it is not always possible for individuals to gain the desired knowledge and skills. In general, it is very hard to make students be attentive in lessons, make them a part of the process, or encourage them to participate actively in the lessons due to teacher-centered teaching methods and techniques (MEB, 2005; Duru, 2014). In these teacher-centered classes, the teachers have the active role and even competent students are often unsuccessful in learning. Einstein, for example, was in a similar environment that did not facilitate high-level thinking skills and he was assessed as an unsuccessful student. Einstein linked the cause of this situation to the education process it received and teaching methods. And he said "The only thing that interferes with my learning is my education." Therefore, instead of teaching techniques and methods that restrict students to what the teacher teaches make them dependent on the textbook and adversely affect their will to learn; it is necessary to use student-centered methods and techniques that direct students toward learning by searching, examining, thinking, experiencing for themselves, developing their own sense of responsibility, improving communicative skills, and increasing their group interactions (Güven, 2011). As a result, this study concerns the project-based learning (PBL) method in which the projects were prepared by the students.

PBL is an approach in which the students, as individuals or in groups, investigate a subject determined by real-life problems and carry out their studies based on cooperative research, and their study results in realistic products or presentations (Demirhan, 2002). The goal of PBL is to provide the students with creative learning experiences. That is, the purpose of PBL is to enable the student to learn about the subject through his/her own experiences and not to answer a question that the teacher proposes or to solve a problem. During the project studies, the students put forward their own genuine ideas concerning the problem and learn by themselves by converting these ideas into actual materials. In this way, the students learn to listen, talk, and determine as a team using their minds creatively, independently, and responsibly. In addition, their abilities in 
planning, organization, research, and time management, which are extremely important for their future academic lives, are improved (Fleming, 2000).

The usage of PBL in science, and especially physics classes, considering the contribution it makes to the student's learning, is important (Korkmaz and Kaptan, 2001; Seloni, 2005; Görecek, 2007; Baran and Maskan, 2010; Panasan and Nuangchalerm, 2010). The majority of students perceive physics lessons to be difficult and as such are concerned or even scared with not being able to understand the lesson material. Researches have highlighted reasons for these negative preconceptions are that the students find this subject abstract and therefore they cannot associate the subjects with their daily life (Williams et al., 2003; Barmby and Defty, 2006; Kessels et al., 2006; Karakuyu, 2008; Ornek et al., 2008; Gebbels et al., 2010; Şahin and Yağbasan, 2012). On the other hand, one of the most important features of PBL is linking the students' daily life with the theoretical knowledge learned in class (Solomon, 2003). According to Isbell (2004; 2005), the information and the real-world problems are reinforced, and an interdisciplinary and student-based practice is carried out during the lessons studied with PBL. In this way, the students not only are able to have fun during the education process but also learn by experience (Raghavan et al., 2001). Moreover, according to Anderson (2010), through PBL, students experience real-life with the approaches they create in a risk-free environment. PBL creates a bond between previous learning, new learning, and real-life experiences. In this way, the students develop scientific abilities that they can use in their lives. As such, PBL has a positive influential on the subjects and lessons that are considered difficult to grasp and deemed to abstract. However, there is not enough importance given in teacher education universities to PBL despite these benefits for students and education environments (Akdeniz and Devecioğlu, 2001).

Teacher candidates need knowledge on modern teaching methods such as PBL, exhibition experiments, and explanatory patterns. They also need to examine those techniques that support students' learning and facilitate education. They need the ability and knowledge to apply these methods as teachers they will play an extremely important role in the upbringing of the next generation (Ekici, 2000; Saka and Akdeniz, 2001). In this respect, this research aimed to study the influence of PBL on physics and technologies, a project exhibition event based on the PBL activity, and the success of the physics teacher candidates. This research study sought to reveal the views of the experimental group of teacher candidates who received an education with PBL.

In Turkey, very few project exhibitions are organized around students' work. As a result, original student projects are available to very few people. In addition, the number of studies investigating the effect of student project exhibitions on success are quite limited. In this respect, it is thought that this study will contribute to this area in terms of improving the original project production and increasing the incentives for the project exhibition regulations.

\section{METHOD}

\section{Research Design}

In this research, the research model called explanatory mixed method, in which both quantitative and qualitative research methods used together had been applied (Creswell, 2014). To collect the quantitative data, a pre-test/post-test control and experimental group design were used. Then, interviews gathered qualitative data to explore and explain the results obtained from the quantitative data.

\section{Research Sample}

The participants were selected with a purposive sample. This enables the researcher to choose participants who are believed to find solutions to the problem being studied (Cohen et al., 2007). In this study, the researchers chose a state university situated in Ankara and chose the "physics and technology" course for this research. The working group of the research consists of two classes of prospective teachers $(n=65)$ taking the "physics and technology" course. These participants were in their $2^{\text {nd }}$ Grade when this study took place in the 2012-2013 spring term of the academic year. One of these classes was selected randomly as the experiment group $(n=31)$ and the other as the control group $(n=34)$.

In the quantitative phase, all the prospective teachers $(n=65)$ participated. After analyzing the quantitative data obtained from the prospective teachers, the experiment group's point average was ranked as lower $1 / 3$, medium $1 / 3$, and upper $1 / 3$ for the qualitative phase. Semi-structured interviews were conducted with six prospective teachers from the experiment group. Three men and three women were selected, one male and one female from each of the three ranked groups.

\section{Research Instruments}

In this study, the physics achievement test (PAT) and semistructured interview questions that were developed by the researchers were used as the data collection tools.

\section{PAT}

The achievement test used in this study was prepared by the researchers to include basic definitions, concepts, and information in the physics and technology issues that were part of the 13 weeks of lectures for both experiment and control groups. In the development process of the test, a review of the literature was conducted. Then, using general physics and special topics in physics textbooks, a scale was developed which contained multiple-choice questions based on Bloom's Taxonomy (Balta, 2009; Can Şen and Eryılmaz, 2011; Serway and Beichner, 2011; 2012). The questions were reviewed by an academic member for content validity, by another academic member for conformity with assessment and evaluation principles, and by a third academic member for grammar and clarity. Due to this review, some of the 
questions were excluded, some were changed in line with the expert opinions, and a final version consisting of 42 questions was prepared. This survey was piloted on $1833^{\text {rd }}$ and $4^{\text {th }}$ year students studying in the Science Education Department to determine the reliability of the questions. Later, the items were analyzed and test analysis was carried out. In the item analysis, the difficulty (pj) and discrimination indexes (rjx) of all the items were calculated, and texts were made from 33 items whose item difficulty was between 0.41 and 0.62 and discrimination index was 0.31 and 0.58 (Köklü et al., 2006). Difficulty and discrimination indexes of the items are given in Table 1.

Test analyzes were done through test points, and the results regarding analyzes are given in Table 2.

When the data given in Table 2 were examined, the KR20 reliability (Tan, 2009) of the achievement test was determined as 0.76 and the standard deviation was 5.62. Each of the questions of the achievement test containing 33 questions was transferred to table of specifications in line with Bloom's Taxonomy and content validity of the test was found adequate. After completing validity and reliability analyses, an achievement test consisting of 33 questions was obtained. The average response time of the test was $50 \mathrm{~min}$, and the maximum score that can be obtained from the test is 33 points.

\section{Semi-structured interview questions}

The qualitative data were collected with the semi-structured interview technique enabling precise and detailed definitions made with prospective teachers (Punch, 2005). An interview protocol was prepared by the researchers, and during the interview, the order in this form was followed. The interviews were recorded with a voice recorder with the permission of the participants with the aim of converting into a written text in electronic environment. In the findings, prospective teachers

\begin{tabular}{lcccccccc}
\hline \multicolumn{7}{l}{ Table 1: Achievement test item analysis results } \\
\hline Item & $\mathbf{p j}$ & rjx & item & pj & rjx & item & Pj & rjx \\
\hline 1 & 0.49 & 0.41 & 12 & 0.55 & 0.54 & 23 & 0.49 & 0.45 \\
2 & 0.42 & 0.34 & 13 & 0.42 & 0.34 & 24 & 0.54 & 0.39 \\
3 & 0.50 & 0.31 & 14 & 0.53 & 0.57 & 25 & 0.62 & 0.40 \\
4 & 0.48 & 0.36 & 15 & 0.47 & 0.45 & 26 & 0.58 & 0.56 \\
5 & 0.46 & 0.49 & 16 & 0.50 & 0.38 & 27 & 0.53 & 0.36 \\
6 & 0.50 & 0.51 & 17 & 0.46 & 0.44 & 28 & 0.46 & 0.36 \\
7 & 0.41 & 0.40 & 18 & 0.58 & 0.44 & 29 & 0.59 & 0.32 \\
8 & 0.49 & 0.39 & 19 & 0.44 & 0.50 & 30 & 0.47 & 0.41 \\
9 & 0.57 & 0.33 & 20 & 0.53 & 0.41 & 31 & 0.41 & 0.44 \\
10 & 0.50 & 0.33 & 21 & 0.56 & 0.43 & 32 & 0.60 & 0.32 \\
11 & 0.43 & 0.48 & 22 & 0.48 & 0.58 & 33 & 0.45 & 0.49 \\
\hline
\end{tabular}

\section{Table 2: Achievement test item results}

\begin{tabular}{lccccc}
\hline $\boldsymbol{n}$ & $\mathbf{M}$ & $\mathbf{d f}$ & Median & Mode & KR-20 \\
\hline 183 & 19.87 & 5.62 & 19 & 21 & 0.76 \\
\hline
\end{tabular}

were given a code name (S1, S2, S3...). The questions were as follows:

1. What do you think about the learning method (PBL) used in the lesson?

2. What do you think you learnt while preparing and presenting your project?

3. How did you evaluate the project you have done, considering the positive and negative criticism to your project study you received during the project exhibition?

\section{Research Procedure}

As stated, the data collection was carried out in the physics and technologies course during the spring term of the participants $2^{\text {nd }}$ year in their science teaching undergraduate program, as well as the project exhibition organized by the study's Faculty of Education at the end of the term. The teaching of the subjects within the context of physics and technologies was carried out with PBL for the teacher candidates in the experimental group, while it was carried out using the interactive lecture method for the teacher candidates in the control group. As part of this study, the teacher candidates in the experimental group participated in a project exhibition organized by the Faculty of Education, with their original projects (see appendix).

Before the activity started, a seminar was given to the teacher candidates in the experimental group explaining PBL and what would be required. As part of this seminar, the project exhibition activity organized by the university was explained. Participating teacher candidates were informed of the specifics required to participate in this exhibition. Specifically, teacher candidates were to develop original projects that would not include distressed material and would appeal to students aged between 6 and 11 .

The PAT was offered as a pre-test to both groups. At the end of the study, the PAT was offered again to both of the groups as a post-test. The teacher candidates in the experimental group participated in the project exhibition organized by the Faculty of Education. The project exhibition was open for 3 days, and primary and junior high school students visited the exhibition. In this way, the teacher candidates in the experimental group found the chance to present the projects that they prepared to people from primary school students to university students and academics that came to see the project exhibition.

The data regarding pre- and post-test points belonging to both groups were analyzed by statistical analysis methods, and the differences between the groups in terms of efficiency of the methods applied were examined. After that, the six participants (three men and three women) selected from experiment group were interviewed to complete the data collection process.

\section{Data Analysis}

Quantitative data were analyzed using the Microsoft Excel 2007 spreadsheet program and SPSS 18 statistical analysis program. To investigate whether there was a normal distribution of quantitative data, descriptive statistical techniques were used. The scores obtained from post-test determined the bottom $1 / 3$, middle $1 / 3$, and top $1 / 3$ groups to select interview participants. 
Independent sample $t$-test determined whether there was a statistical difference that the associated population means were significantly different, and the significance level was set at $P<0.05$. Qualitative data obtained from the research were analyzed using Miles and Huberman (1994) and Yıldırım and Şimşek's (2008) content analysis. The interview results were transcribed and analyzed with the HyperRESEARCHTM 2.6.1 qualitative analysis program.

\section{FINDINGS}

\section{Findings Related to Quantitative Results}

In quantitative research, both parametric and non-parametric statistical methods can be used to analyze the data. Quantitative data obtained from all applied tests and scales during the research should reflect the normal distribution to use parametric analysis methods to analyze the data (Sim and Wright, 2002). For this reason, analyzes were conducted to determine the statistical methods to be applied to the data obtained from the PAT and investigated whether scores showed a normal distribution (Table 3).

When we examined Table 3, both the average regarding pretest, mode, and median values of the experiment group and mode, average, and median values about pre-test points of control group were very close. Similarly, the average regarding the post-test, mode, and median values of the experiment group and the average, mode, and median values about the post-test points of control group were almost the same. The fact that average, mode, and median values are very close to each other interpreted as that the data have a normal distribution (Köklü et al., 2006). When the kurtosis and skewness values in Table 3 were examined, it was seen that the values were between -2 and +2 interval and the data were distributed normally (George and Mallery, 2003). Furthermore, for both of the groups as the sample magnitude $n>30$, it was assumed that the data were distributed normally according to the central limit theorem (Gosling, 2004; Russell and Purcell, 2009).

The analysis of the data determined that there was a normal distribution. To prove homogeneity of each group, dependent variables were compared before treatment using independent sample $t$-test.

As it shown in Table 4, there is no significant difference between experimental $(\mathrm{M}=16.45)$ and control group $(\mathrm{M}=16.59)$ students' scores of pre-test PAT $(P>0.05, t=-0.240)$.

In the analysis regarding pre- and post-test PAT of the experiment and control groups to determine the efficiency of the PBL versus lecture, independent sample $t$-test was used.

According to the data in Table 5, it is seen that achievement point averages of the prospective teachers in experiment group (PBL) and control group (lecture) showed a significant difference $(P<0.05)$.

\section{Findings Related to Qualitative Results}

Three open-ended questions were offered to selected teachers to collect qualitative data. The qualitative data were analyzed with qualitative research methods using codes and themes and by directly quoting from prospective teachers.

First, the question "what do you think about the teaching method (PBL) used in the lesson?" was posed to the prospective teachers. The percent-frequency table regarding the codes and themes obtained by analyzes and the distribution of the answers made by the prospective teachers on the codes and themes is given in Table 6.

On reviewing the statements of the teacher candidates about the PBL method, it can be seen that the candidates made comments that revealed the pros and cons of the method. Almost all of these teacher candidates stated that the method enabled them to understand the subject, linked the theory with the practice, increased their productivity, supported them thinking scientifically, and to conduct research. The cons of the PBL method included not being able to come up with any project ideas, put theoretically found ideas into practice, necessity to work for long times, and the method being a tiring activity. The following are representative quotes from teacher candidates.

S3: I never used PBL method before. I mean, I knew about its content, but I never applied it. But now, I absolutely think that it must be used in science lessons, especially ones that include subjects from physics. Because this method enables the subject to be learnt completely, and that is very crucial for science lessons. You can put the information you've learned about the subject into practice. However, we had a little bit of difficulty about the subject. Because we didn't know how to objectify and materialize a project idea that we actually had a hard time finding, thinking about it for a really long time. This part stressed us out and tired us very much as a group. But in the end when we completed the project, we felt that it was worth it. Because we created it ourselves, you know. $(84.638,17.04 .2015)^{1}$

S6: This is absolutely a marvelous method. I never understood the physics as clearly as this (laughing). I'm always scared of physics lessons anyway, but now that we've turned them into projects I'm asking myself why in the world I was not able to understand these subjects when I think about it. So this is what is called to put the information you learn in lessons into practice in daily life. And although we understood that it isn't easy to perform, you really succeed if you think like a scientist and work for a long time. And finally the project that you created yourself emerges. I think it is really a great method. I saw lots of projects that I never thought I'd see or think in this exhibition. (73.991, 17.04.2015).

Then, the question "what do you think you learnt while preparing and presenting your project?" was posed to the prospective teachers. The percent-frequency table regarding the codes and themes obtained by analyzes and the distribution of the answers made by the prospective teachers on the codes and themes is given in Table 7.

1 First code is a Reference number assigned by HyperRESEARCHTM 2.6.1, second code is date of interview 


\begin{tabular}{|c|c|c|c|c|c|c|c|c|}
\hline Test & Group & $n$ & M & df & Median & Mode & Kurt & Skew \\
\hline \multirow[t]{2}{*}{ Pre } & Experiment & 31 & 16.45 & 2.307 & 17.00 & 16 & -0.352 & 0.085 \\
\hline & Control & 34 & 16.59 & 2.285 & 17.00 & 18 & -0.202 & -0.061 \\
\hline \multirow[t]{2}{*}{ Post } & Experiment & 31 & 21.10 & 3.673 & 20.00 & 20 & 0.146 & -0.344 \\
\hline & Control & 34 & 19.29 & 3.070 & 20.00 & 19 & 0.085 & -0.258 \\
\hline
\end{tabular}

PAT: Physics achievement test

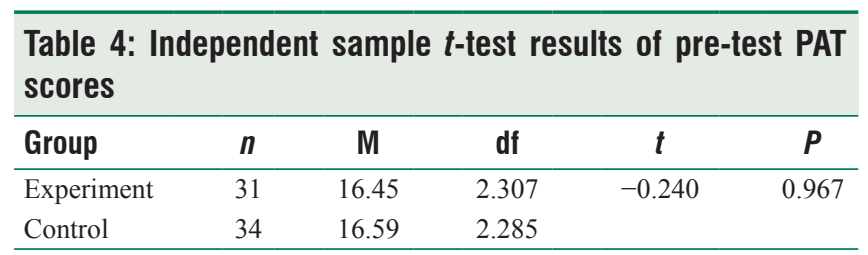

PAT: Physics achievement test

\begin{tabular}{|c|c|c|c|c|c|}
\hline Group & $n$ & M & df & $t$ & $P$ \\
\hline Experiment & 31 & 21.10 & 3.673 & 1.697 & 0.035 \\
\hline Control & 34 & 19.29 & 3.070 & & \\
\hline
\end{tabular}

PAT: Physics achievement test

From Table 7, it can be seen that the candidates' answers were thematized as cognitive, affective, and psychomotor learnings. Below are exemplar student teacher quotes.

S1: Well... If I should first talk about the gains I had upon preparing, I learned about the subject, its formulas and stuff to begin with. And after I learned about the subject, I grasped how I could produce the project in a better way. While producing the project I learned how to install electronical devices, computer programs, connections and so forth. Then together with my friends from the group I made a model from cardboard. Then we assembled the connections to the proper parts of the model. Then we painted the model and turned it into something colorful and attractive, this part was real fun. Together, we applied a theoretical information that we knew on a model after all. I absolutely felt like a teacher when we reached the presentation stage. It was very exciting. We always thought about how we could present or talk about our project in the best way and so on. We decided on how we could convey our project to the people coming to the exhibition in the most thorough way, and we made great presentations. $(142.396,17.04 .2015)$.

S4: I mean the presentation part went great for us. We were very excited, and we wanted talk about it to everybody, you know. However, I really think that we explained the project very well, everybody really liked it. They stopped and asked questions to us about the project. About the catchy parts... Then we talked with them face to face and conveyed to them the project and the physics subject in which the project took part thoroughly. Some teachers gave some advices on how to better the project. For example, we decided as a group that these advises could really better the project. But the preparation part... We really had some difficulty in this part. However, it was actually really fun. It was really nice to use the creativity, think on some stuff, consider the matter from a different angle and on and on, you know. I especially think that the model-making process earned us lots of things. Because I worked on this model more than I ever bothered before, and we turned the subject that we knew into a product for the daily life. $(179.109,17.04 .2015)$.

Finally, the last question "how did you evaluate the project you have done, considering the positive and negative criticism to your project study you received during the project exhibition?" was posed to the prospective teachers. The percent-frequency table regarding the codes and themes obtained by analyzes and the distribution of the answers made by the prospective teachers on the codes and themes is given in Table 8 .

According to the candidates, the positive sides of the projects they put forward were that the projects were useful, beneficial, successful, easily producible, original, and technological; while the negative sides were that the projects were costly, they turned out to be useless in various situations, and they required a great deal of time to complete. Teacher candidate comments are as follows:

S2: I think our project is great. Everybody that visited the exhibition said the same thing anyway. For example, they said that it is very useful and beneficial for everyone. Think for one second how beneficial this project would be for the roads if it was actually implemented. I think the only troubling part of the project is that it is a little high-priced. Especially, the magnetics of that kind are really hard to find and very expensive. However, when we consider this for the government, everything could be easy to find. Still, I am sure that its benefits would be a lot despite the money and labor force spent. (223.454, 17.04.2015).

S5: First, I think that we created a product that can work and is successful. The idea is very original for one thing and has an extremely technological structure. Moreover, since it is technology intensive, it can be produced easily. We did not have as much trouble creating it as our other colleagues. However, this can be a negative sign of the project on the other hand. Because it makes this project useless and very expensive for the places where technology is not developed. Still, I am really glad for what we have done $(296.302,17.04 .2015)$.

\section{RESULTS AND DISCUSSION}

The effect of the PBL method and project exhibition event on the success toward the physics subjects was one of the foci of 


\begin{tabular}{|c|c|c|c|}
\hline Question & Theme & Code & $f(\%)$ \\
\hline \multirow{9}{*}{$\begin{array}{l}\text { What do you think about the teaching } \\
\text { method (PBL) used in the lesson? }\end{array}$} & Advantages of the teaching method & Provide better understanding of the subject & $6(100)$ \\
\hline & & Merge the theoretical with application & $5(83.3)$ \\
\hline & & Increase the efficiency & $4(66.7)$ \\
\hline & & Gain the scientific thinking skills & $3(50)$ \\
\hline & & Teach to do research & $3(50)$ \\
\hline & Disadvantages of the teaching method & Inability to find the original idea & $4(66.7)$ \\
\hline & & Inability to transform theoretical ideas into practice & $4(66.7)$ \\
\hline & & Require long-term studies & $3(50)$ \\
\hline & & Be tiring & $2(33.3)$ \\
\hline
\end{tabular}

PBL: Project-based learning

\begin{tabular}{|c|c|c|c|}
\hline Question & Theme & Code & $f(\%)$ \\
\hline \multicolumn{4}{|c|}{$\begin{array}{l}\text { What do you think you perform to learn while } \\
\text { preparing and presenting your project? }\end{array}$} \\
\hline \multirow[t]{10}{*}{ Preparing } & Cognitive learning & Learning subject (formulas and equations) & $5(83.3)$ \\
\hline & & Learning scientific thinking & $3(50)$ \\
\hline & & Learning planned study & $2(33.3)$ \\
\hline & Affective learning & Increasing creativity & $3(50)$ \\
\hline & & Feeling responsibility & $3(50)$ \\
\hline & & Providing a positive commitment between group members & $2(33.3)$ \\
\hline & Psychomotor learning & Developing handicraft & $4(66.7)$ \\
\hline & & Practicing theoretical knowledge to everyday life & $4(66.7)$ \\
\hline & & Acquiring knowledge transfer to model & $3(50)$ \\
\hline & & Using technology & $2(33.3)$ \\
\hline \multirow[t]{8}{*}{ Presenting } & Cognitive learning & Using teaching techniques & $3(50)$ \\
\hline & & Providing active learning & $2(33.3)$ \\
\hline & Affective learning & Feeling the excitement and desire to explain the product & $4(66.7)$ \\
\hline & & Feeling like a teacher & $3(50)$ \\
\hline & & Providing motivation & $2(33.3)$ \\
\hline & & Learning to think critically & $1(16.7)$ \\
\hline & Psychomotor learning & Developing presentation skills & $5(3.3)$ \\
\hline & & Improving communication skills & $3(50)$ \\
\hline
\end{tabular}

Table 8: Percent-frequency distributions of theme and codes belongs to third question

\begin{tabular}{|c|c|c|c|}
\hline Question & Theme & Code & $f(\%)$ \\
\hline \multirow{9}{*}{$\begin{array}{l}\text { How do you evaluate the project you have done, considering } \\
\text { the positive and negative criticism to your project study you } \\
\text { have received during the project exhibition? }\end{array}$} & The positive aspects of my project & Useful & $5(83.3)$ \\
\hline & & Helpful & $3(50)$ \\
\hline & & Successful & $3(50)$ \\
\hline & & Easy to manufacture & $3(50)$ \\
\hline & & Original & $2(33.3)$ \\
\hline & & Technological & $1(16.7)$ \\
\hline & The negative aspects of my project & Costly & $4(66.7)$ \\
\hline & & Unusable in some cases & $2(33.3)$ \\
\hline & & Produced by long-term studies & $2(33.3)$ \\
\hline
\end{tabular}

this research. The findings obtained from Table 5 show that there was a significant difference in favor of the experiment group among the point averages of the achievement posttest of the groups $(P<0.05)$. The experiment group students were more successful than the control group students according to the results of the achievement test. These results support 
similar studies on the positive influence of PBL method on student success in physics (Renata, 2008; Altun et al., 2009; Köse, 2010; Baran and Maskan, 2010; Keskin, 2011; Ergül and Kargın, 2014; Yılmaz, 2015; Akın, 2016).

The experimental group of teacher candidates exhibited their projects in a project exhibition. Research has shown the positive influence of such exhibitions on interest and success toward science (Czerniak, 1996; Cook, 2003; Çiçek, 2008). In studies in the literature, either the impact of PBL on physics success or the contribution of project exhibitions to science courses was examined. This study supports research on the positive effect of both the PBL method and project exhibitions on the science courses. However, this study combined these two works to investigate the success of the physics course of prospective teachers with the project exhibition activity. This is significant since prospective teachers do not have many chances to undertake project applications during their university education. University education in Turkey does not require such an implementation process. However, it is arguable that prospective teachers could only manage the implementation of PBL through their own participation in the process of project construction, management, and exhibition. Thus, it is argued that the positive experiences gained during this research study will contribute to the experimental group's professional lives.

The second aim of this study was to reveal the views of the candidates in the experimental group about the PBL method and the project exhibition event. The teacher candidates stated that the method enabled them to understand the subject better, linked the theory with the practice, increased their productivity, supported them thinking scientifically, and to conduct research. This study supports research in how PBL facilitates student learning.

Çakan (2005) and Larmer and Mergendoller (2010) revealed that PBL enabled the information to be understood better and more expressively. According to Solomon (2003), the students gained experience by increasing their ability of problemsolving, associates the theoretical information with their daily life, and solved the problem by harmonizing the information that they obtained from various sources with their previous knowledge. PBL supported students in planning, creating, and being a more productive person (Erdem and Akkoyunlu, 2002). According to Frank and Barzilai (2004), students can use their dominant thinking abilities and develop different thinking paths to solve problems, with their project studies. Similarly, Erdem and Akkoyunlu (2002), Larmer and Mergerdoller (2010), and Borhan and Ismail (2011) highlighted that the projects gave students the ability of apply scientific, crucial, and critical thinking and develop their abilities of high-level thinking and problem solving.

Some of the teacher candidates in this study noted that they were not able to come up with project ideas or put theoretical ideas into practice. They also reported that the PBL project necessitated a long time to complete and this method was tiring. The issue of PBL taking more time has been reported in previous research (Krajcik et al., 1999; Demirhan, 2002; Grant, 2002; Yurtluk, 2003; Ayvacı and Çoruhlu, 2010).

The question "what do you think you learnt while preparing and presenting your project?" was offered to the teacher candidates. The candidates gave answers stating that they carried out cognitive, affective, and psychomotor learnings in both the preparation and the presentation stages to this question (Table 7). The candidates' coded responses on the project preparation stage supported relevant literature, namely, learning the subject (Thomas, 2000), learning to think scientifically (Raghavan et al., 2001), increasing their creativity (Girgin, 2003), feeling responsibility for learning (Dori and Tal, 2000; Baysura et al., 2016), providing a positive relationship among group members (Yurtluk, 2003), upskilling their handicraft (Gültekin, 2007), and implementing the theoretical information on the daily life (Güven, 2011). Similarly, the coded responses on the presentation stage supported using teaching strategies (Erdem and Akkoyunlu, 2002), feeling excitement and desire (Budak et al., 2006), generating motivation (Frank and Barzilai, 2004), learning to think critically (Erdoğan, 2007), and improving their abilities of presentation and communication (Saracaloğlu et al., 2006). According to Demirel et al. (2000), students carry out cognitive, affective, and psychomotor learnings with PBL.

Within the scope of the results obtained from the research, the opinions of the prospective teachers were gathered about PBL. There are very few studies on the project presentation process (Küfrevioğlu et al., 2011; Tortop, 2013; Avc1 et al., 2016). Importantly, these prospective teachers responded to the question about the PBL considered their experiences in both project preparation and presentation of their projects at the project exhibition event. In this way, not only the advantages and disadvantages of the project preparation step but also the advantages and disadvantages of projects presentation step were revealed. Furthermore, unlike other studies, the prospective teachers' learnings at the stage of project preparation and presentation were taxonomically themed. Candidates' learnings at the stage of project preparation and presentation were presented separately as cognitive, affective, and psychomotor learning.

Finally, the question "how did you evaluate the project that you have prepared, considering the negative and positive criticism you received for your project during the project exhibition?" was addressed by the teacher candidates. According to the candidates, the positive sides of their projects were that the projects were useful, beneficial, successful, easily producible, original, and technological. According to Fleming (2000), students should be lead to create satisfactory products in terms of creativity, originality, success, and usefulness when they are being directed to the project studies. For these candidates, the negative aspects of the projects were that the projects were costly, they turned out to be useless for various situations, and they could only be produced after a long time working on them. 
Research has reported that sources, materials, environment, and equipment required to carry out the projects may not always be possible, and a lot of time is needed to create the projects (Girgin, 2003; Erdoğan, 2007).

It can be understood from their statements that the teacher candidates formed positive thoughts and attitudes toward the project exhibition. Unfortunately, in Turkey, there are not enough project-based activities in public schools (Şimşek et al., 2012) and teachers have difficulty when trying to carry out project studies (Baki and Bütüner 2009; Öztuna and Diker, 2012). This study highlights that there were clear positives due to the preparation and presentation of projects. In this respect, it is an ideal situation for prospective teachers who will guide the future generations to experience the steps of preparing and presenting PBL while undertaking their university education. This is because it is very difficult for individuals who did not experience activities such as PBL and project exhibitions during their education to go to primary and secondary schools and carry out project studies with the students there.

\section{REFERENCES}

Akdeniz, A.R., \& Devecioğlu, Y. (2001). Ortaögretim Fizik Derslerinde Yürütülen Proje Çalışmalarının Değerlendirilmesi. [Evaluation of the Project Work Carried out in Secondary Physics Courses]. Istanbul: Science Education Symposium, Marmara University Education Faculty.

Akın, D. (2016). Sinıf Sosyal Bilgiler Dersinde Proje Tabanlı Öğrenmenin Öğrencinin Akademik Başarısına ve Derse Karşı Tutumuna Etkisi. [In Social Sciences class-6 the Effect of Academic Success and Course Attitude of Project-based Learning of Students]. Yayınlanmamış Yüksek Lisans Tezi, Fırat Üniversitesi, Eğitim Bilimleri Enstitüsü, Elazığ.

Altun, Y.S., Turgut, U., \& Büyükkasap, E. (2009). The effect of project based learning on science undergraduates' learning of electricity, attitude towards physics and scientific process skills. International Online Journal of Educational Sciences, 1(1), 81-105.

Anderson, J. (2010). Interdisciplinary project-based learning leads to success. Tech Directions, 70(4), 20-21.

Avcı, E., Özenir, Ö.S., \& Yücel, E. (2016). Tübitak ortaöğretim öğrencileri araştırma projeleri yarışmasına katılan öğrencilerin yarışma sürecindeki deneyimlerinin üniversite yaşamlarına yansıması. [Students' experiences during Tübitak secondary education students research projects competition and its contribution to their university life]. Uşak Üniversitesi Sosyal Bilimler Dergisi, 9(3), 1-21.

Ayas, A., Karamustafaoğlu, O., Sevim, S., \& Karamustafaoğlu, S. (2002). Genel kimya laboratuar uygulamalarının öğrenci ve öğretim elemanı gözüyle değerlendirilmesi. [Academicians' and students' views of general chemistry laboratory applications]. Hacettepe Üniversitesi Eğitim Fakültesi Dergisi, 23, 50-56.

Ayvacı, H.Ş., \& Çoruhlu, T. (2010). Fen ve teknoloji dersi proje tabanlı öğretim uygulamasında ilköğretim öğrencilerinin karşılaştıkları güçlükler. [Project based learning environments in science and technology instruction and students' problems]. Uludă̆ Eğitim Fakültesi Dergisi, 23(1), 43-59.

Baki, A., \& Bütüner, S.Ö. (2009). Kırsal kesimdeki bir ilköğretim okulunda proje yürütme sürecinden yansımalar. [Reflections on the project implementation process in a primary school in rural area]. Illkögretim Online, 8(1). 146-158.

Balta, N. (2009). Kritik Düşünme Gerektiren Fizik Sorularl ve Bunların Öğrencilerin Başarısına Etkisi. [Counterintuitive Physics Problems and Effect of these Problems on Student Success]. Ankara: Yayınlanmamış Yüksek Lisans Tezi, Gazi Üniversitesi, Eğitim Bilimleri Enstitüsü.

Baran, M., \& Maskan, A. (2010). The effect of project-based learning on preservice physics teachers electrostatic achievements. Cypriot Journal of Educational Sciences, 5(4), 243-257.
Barmby, P., \& Defty, N. (2006). Secondary school pupils' perceptions of physics. Research in Science and Technological Education, 24(2), 199-215.

Baysura, O.D., Altun, S., \& Yucel, T.B. (2016). Perceptions of teacher candidates regarding project-based learning. Eurasian Journal of Educational Research, 62, 15-36.

Borhan, M.T., \& Ismail, Z. (2011). Promoting environmental stewardship through project based learning. International Journal of Humanities and Social Science, 1(4), 180-186.

Budak, E., Nalçac1, N., \& Köseoğlu, F. (2006). Proje Tabanlı Öğrenme Yaklaşımında Öğretmenlerin Karşılaştığ G Güçlükler ve Yaklaşımın Ögrenciler Üzerindeki Etkileri. [The Effect of Project-based Learning Approach on the Difficulties Faced by Teachers and on Students]. Ankara: Ulusal Fen Bilimleri ve Matematik Eğitimi Kongresi.

Can Şen, H., \& Eryılmaz, A. (2011). Bir başarı testi geliştirme çalışması: Basit elektrik devreleri başarı testi geçerlik ve güvenirlik araştırması. [An achievement test development study: Reliability and validity investigation of simple electric circuits achievement test]. Yüzüncü Yll Üniversitesi, Eğitim Fakültesi Dergisi, 3(1), 1-39.

Cansüngü, Ö. (2000). Illköğretim Öğrencilerinin (5., 6. ve 7. Sinıflar) Işılk ve Işılkla Ilgili Kavramlar Algllama Şekillerinin Tespiti Üzerine bir Araştırma. [A Research Study to Determine Primary School $\left(5^{\text {th }}, 6^{\text {th }}\right.$ and $7^{\text {th }}$ grade) Students Concepts Concerning Light and its Properties]. Ankara: Yayımlanmamış Yüksek Lisans Tezi. Gazi Üniversitesi Eğitim Bilimleri Enstitüsü.

Cohen, L., Manion, L., \& Morrison, K. (2007). Research Methods in Education. London: Routledge Falmer.

Cook, H.M. (2003). Elementary School Teachers and Successful Science Fairs. Unpublished Doctoral Thesis. Greensboro: The Faculty of the Graduate School at North Carolina.

Creswell, J.W0. (2014). Research Design. Qualitative, Quantitative, and Mixed Methods Approaches. $4^{\text {th }}$ ed. Thousand Oaks, CA: Sage Publication.

Czerniak, C.M. (1996). Predictors of success in a district science fair competition: An exploratory study. School Science and Mathematics, 96(1), 21-28.

Çakan, S. (2005). Proje Tabanlı Öğrenme Yaklaşımının Uygulandığı 6. Sinıf Matematik Dersine Ilişkin Öğrenci ve Öğretmen Görüşleri (Bir Eylem Araştırması). [Student and Teachers views about a Sixth Grade Math Lesson that used the Project Based Learning Approach (an action Research)]. Balıkesir: Yayımlanmamış Yüksek Lisans Tezi. Balıkesir Üniversitesi Fen Bilimleri Enstitüsü.

Çiçek, Ş. (2008). Lise 2 Öğrencilerinin Kimya Dersinde Başarıları ve Tutumlarl üzerine Bilim Şenliklerinin Etkisinin Incelenmesi. [The Study of the Effects of Science Fairs on the Success and Behaviours Towards Chemistry]. Ankara: Yayımlanmamış Yüksek Lisans Tezi. Gazi Üniversitesi Eğitim Bilimleri Enstitüsü.

Demirel, Ö., Başbay, A., Uyangör, N., \& Bıyıklı, C. (2000). Proje Tabanlı Öğrenme Modelinin Öğrenme Sürecine ve Öğrenci Tutumlarına Etkisi. [The Effect of Project-Based Learning Model on the Learning Process and Students' Attitudes]. Bolu: Eğitim Bilimleri Kongresi, Abant İzzet Baysal Üniversitesi.

Demirhan, C. (2002). Program Geliştirmede Proje Tabanl Öğrenme Yaklaşımı. [Project-Based Learning Approach in Curriculum Development]. Ankara: Yayımlanmamış Yüksek Lisans Tezi. Hacettepe Üniversitesi Sosyal Bilimler Enstitüsü.

Dori, Y., \& Tal, R. (2000). Formal and informal collaborate projects: Engaging in industry with environment awareness. Science Education, 84(1), 1-19.

Duru, S. (2014). Yapılandırmacı ve geleneksel öğrenme ortamlarının öğretmen adaylarının eğitim inançları üzerine etkisi. [The effect of constructivist and traditional learning environment on student teachers' educational beliefs]. Pamukkale Üniversitesi Eğitim Fakültesi Dergisi, 36(2), 15-28.

Ekici, G. (2000). Biyoloji öğretmenlerinin öğretimde kullandıkları yöntemler ve karşılaştıkları sorunlar. [Methods used in the teaching of biology teachers and their problems]. Kuram ve Uygulamada Eğitim Yönetimi, 24, 609-620.

Erdem, M., \& Akkoyunlu, B. (2002). İlköğretim sosyal bilgiler dersi kapsamında beşinci sınıf öğrencileriyle yürütülen ekiple proje tabanlı öğrenme üzerine bir çalışma. [A study on project-based learning team carried out with fifth-grade students in elementary social studies] 
İlköğretim Online, 1(1), 2-11.

Erdoğan, G. (2007). Çevre Eğitiminde Küresel Isinma Konusunun Ögrenilmesinde Proje Tabanl Ögrrenmenin Etkisi. [The Effect of Project-based Learning in Environmental Education the Issue of Global Warming]. Zonguldak: Yayımlanmamış Yüksek Lisans Tezi. Karaelmas Üniversitesi Sosyal Bilimler Enstitüsü.

Ergül, R., \& Kargin, K.E. (2014). The effect of project based learning on students' science success. LINELT 2013, Procedia - Social and Behavioral Sciences, 136, 537-541.

Fleming, D.S. (2000). A Teacher's Guide Project-based Learning. Charleston, SC: Appalachia Educational Laboratory (AEL).

Frank, M., \& Barzilai, A. (2004). Integrating alternative assessment in a project-based learning course for pre-service science and technology teachers. Assessment and Evaluation in Higher Education, 29(1), 41-61.

Gebbels, S., Evans, S.M., \& Murphy, L.A. (2010). Making science special for pupils with learning difficulties. British Journal of Special Education, 37(3), 139-147.

George, D., \& Mallery, P. (2003). SPSS for Windows Step by Step: A Simple Guide and Reference. Boston: Allyn \& Bacon.

Girgin, B.A. (2003). Proje Temelli Öğrenme Yönteminin Özel Konya Esentepe İlkögretim Okulu Tarafindan Uygulanmasına Yönelik bir Değerlendirme. [The Evaluation of the Implementation of the Project Based Method by Konya Esentepe Private Elementary School]. Konya: Yayımlanmamış Yüksek Lisans Tezi. Selçuk Üniversitesi Sosyal Bilimler Enstitüsü.

Gosling, J. (2004). Introductory Statistics: A Comprehensive, Self-paced, Step by Step Statistics Course for Tertiary Students. Glebe, Australia: Pascal Press.

Görecek, M. (2007). İlköğretim fen Bilgisi Dersinde tüm Canlılarla Ortak Yuvamız Mavi Gezegenimizi Tanıyalım ve Koruyalım Ünitesinin Proje Çalışmalart ile Öğretiminin Öğrenci Başarısına ve Tutumuna Etkisinin Belirlenmesi. [Investigation of the Effects of using Project Works to Teach the Unit 'Getting to know and Protecting our Planet, we share with all the other Creatures' in Science Course on Student Success and Attitude]. Muğla: Muğla Üniversitesi Fen Bilimler, Enstitüsü (Yayınlanmamış) Yüksek Lisans Tezi.

Grant, M. (2002). Getting grip on project-based learning: Theory, cases and recommendations. Meridian: A Middle School Computer Technologies Journal, 5(1), 1-3.

Gücüm, B. (1998). Fen bilimlerinin oluşumu, gelişimi ve fen bilgisi. [The formation of science, development and science]. In: Yaşar, S., (Ed.), Fen Bilgisi Öğretimi. Eskişehir: Anadolu Üniversitesi Yayınları. pp. 3-11.

Gültekin, M. (2007). Proje tabanlı öğrenmenin 5. Sınıf fen bilgisi dersinde öğrenme ürünlerine etkisi. [The effect of project-based learning on learning products in $5^{\text {th }}$ grade science class]. Illkögretim Online, 6(1), 93-112.

Güven, E. (2011). Çevre Eğitiminde Tahmin-gözlem-açılklama Destekli Proje Tabanlı Öğrenme Yönteminin Farklı Değişkenler Üzerine Etkisi ve Yönteme Ilişkin Öğrenci Görüşleri. [The Effect of Project-based Learning Method Supported by Prediction-Observation-Explanation on Different Variations in Environmental Education and Students views Concerning this Method]. Ankara: Yayımlanmamış Doktora Tezi. Gazi Üniversitesi Eğitim Bilimleri Enstitüsü.

Isbell, K. (2004; 2005). Inside the internet: Project-based learning on the www. Green Teacher, 75, 43.

Karakuyu, Y. (2008). Fizik öğretmenlerinin fizik eğitiminde karşılaştığı sorunlar: Afyonkarahisar örneği. [Problems faced by the physical teacher on physics education: Afyonkarahisar example]. Mustafa Kemal Üniversitesi Sosyal Bilimler Enstitüsü Dergisi, 10(5), 147-159.

Keskin, E. (2011). Proje Tabanll Öğrenme Yönteminin Ilkögretim Ikinci Kademe Öğrencilerinin Bașarı ve fen Motivasyonlarına Etkisinin Incelenmesi. [The Effect of Project-based Learning on Primary Students? Success and Science Motivation]. Bursa: Yayımlanmamıș Yüksek Lisans Tezi, Uludağ Üniversitesi Eğitim Bilimleri Enstitüsü.

Kessels, U., Rau, M., \& Hannover, B. (2006). What goes well with physics? Measuring and altering the image of science. British Journal of Educational Psychology, 76, 761-780.

Korkmaz, H., \& Kaptan, F. (2001). Fen eğitiminde proje tabanlı öğrenme yaklaşımı. [Project-based learning approach in science education]. Hacettepe Üniversitesi Eğitim Fakültesi Dergisi, 20, 193-200.

Köklü, N., Büyüköztürk, Ş., \& Çokluk, B,Ö. (2006). Sosyal Bilimler Için
Istatistik. [The Statistics for the Social Sciences]. Ankara: Pegem A Yayıncilik.

Köse, M. (2010). İlkögretim 7. Sinıf fen ve Teknoloji Dersi Kuvvet ve Hareket Ünitesinin Öğretiminde Proje Tabanlı Öğrenme Yaklaşımının Ögrencilerin Bașarl ve Tutumlarına Etkisi. [The Effect of Teaching Force and Motion Unit by Project-based Learning Approach to the Achievement and Altitude of Science and Technology Lesson of Students at the $7^{\text {th }}$ Class Science and Technology Lesson in Primary School]. Konya: Yayımlanmamıs Yüksek Lisans Tezi, Selçuk Üniversitesi Sosyal Bilimler Enstitüsü.

Krajcik, J.S., Czerniak, C.H., \& Berger, C. (1999). Teaching Children Science a Project Based Approach. Boston, MA: McGraw-Hill.

Küfrevioğlu, R.M., Baydaş, Ö., \& Göktaş, Y. (2011). Proje ve Beceri Yarıșmalarında Elde Edilen Kazanımlar, Karșılaşılan Zorluklar ve Öneriler [Objectives, Challenges and Suggestions of Project and Skill Competitions]. Elazı s̆: $5^{\text {th }}$ International Computer and Instructional Technologies Symposium.

Larmer, J., \& Mergendoller, J.R. (2010). Essentials for project-based learning. Educational Leadership, 68(1), 34-37.

Milli Eğitim Bakanlığı (MEB). (2005). Fen ve Teknoloji Dersi Programı, Ilkögrretim 4-5. Sinif. [Science and Technology Curriculum, Primary Education 4-5. Class]. Ankara: MEB.

Miles, M.B., \& Huberman, A. M. (1994). Qualitative Data Analysis: An Expanded Sourcebook. Thousand Oaks, CA: Sage.

Ornek, F., Robinson, W.R., \& Haugan, M.P. (2008). What makes physics difficult? International Journal of Environmental and Science Education, 3(1), 30-34.

Öztuna, K.A., \& Diker, C.Y. (2012). Proje tabanlı öğretim uygulamalarında karşılaşılan güçlükler ve çözüm önerilerine yönelik bir eylem araştırması. [An action research on the problems in project-based teaching practices and the solution suggestions to these problems]. Mersin Universitesi Eğitim Fakültesi Dergisi, 8(1), 137-159.

Panasan, M., \& Nuangchalerm, P. (2010). Learning outcomes of projectbased and inquiry-based learning activities. Journal of Social Sciences, $6(2), 252-255$

Punch, F.K. (2005). Introduction to Social Research-Quantitative and Qualitative Approaches. London: Sage.

Raghavan, K., Coken, R.S., \& Strobel, S.A. (2001). Student outcomes in a local systemic change project. School Science and Mathematics, 101(8), 417-426.

Renata, H. (2008). Effective teaching methods--project-based learning in physics. US-China Education Review, 5(12), 27-36.

Russell, B., \& Purcell, J. (2009). Online Research Essentials: Designing and Implementing Research Studies. San Francisco, CA: Jossey-Bass, A Wiley Imprint.

Saka, A., \& Akdeniz, A.R. (2001). Biyoloji Öğretmenlerine Çalışma Yaprağ Geliștirme ve Kullanma Becerileri Kazandırmak Için bir Yaklașım. [An Approach to Develop and Provide Worksheets to use Skills of Biology Teachers]. İstanbul: Yeni Bin Yılın Başında Türkiye'de Fen Bilimleri Eğitimi Sempozyumu, Maltepe Üniversitesi.

Saracaloğlu, A.S., Akamca, Ö.G., \& Yeşildere, S. (2006). İlköğretimde proje tabanlı öğrenmenin yeri. [Location of project-based learning in primary education]. Türk Eğitim Bilimleri Dergisi, 4(3), 241-258.

Seloni, R.Ş. (2005). Fen Bilgisi Öğretiminde Oluşan Kavram Yanılgılarının Proje Tabanl Ögrenme ile Giderilmesi. [Resolving the Misconceptions IN Science Education by Project-based Learning Approach]. İstanbul: Yayımlanmamış Yüksek Lisans Tezi, Marmara Üniversitesi.

Serway, R.A., \& Beichner, R.J. (2011). Serway Fizik 2: Elektrik ve Manyetizma-Işık ve Optik. [Serway Physics 2]. Ankara: Palme Yayıncilik.

Serway, R.A., \& Beichner, R.J. (2012). Serway Fizik 1: Mekanik, Mekanik Dalgalar ve Termodinamik. [Serway Physics 1]. Ankara: Palme Yayıncilik.

Sim, J., \& Wright, C. (2002). Research in Health Care: Concepts, Designs and Methods. Cheltenham, UK: Nelson Thornes Ltd.

Solomon, G. (2003). Project based learning: A primer. Technology and Learning, 23(6), 20-30.

Şahin, E., \& Yağbasan, R. (2012). Determining which introductory physics topics pre-service physics teachers have difficulty understanding and what accounts for these difficulties. European Journal of Physics, 33(2), 315-325. 
Şimşek, H., Hırça, N., \& Coşkun, S. (2012). İlköğretim fen ve teknoloji öğretmenlerinin öğretim yöntem ve tekniklerini tercih ve uygulama düzeyleri: Sanlıurfa ili örneği. [Primary science and technology teachers s selection of using teaching methods and techniques and the levels of their applications: The sample of Şanlıurfa city]. Mustafa Kemal Üniversitesi Sosyal Bilimler Enstitüsü Dergisi, 9(18), 249-268.

Tan, Ş. (2009). Misuses of KR-20 and Cronbach's alpha reliability coefficients. Education and Science, 34(152), 101-112.

Thomas, J.W. (2000). A Review of Research on Project-based Learning. Available from: http://www.bobpearlman.org/BestPractices/PBL Research.pdf. [Last accessed on 2017 Sep 09].

Tortop, H.S. (2013). Benim eserimbilim șenliğinin yönetici, öğretmen-öğrenci görüşleri ve fen projelerinin kalitesi odağından görünümü [Overview of a national science fair in Turkey from the focus on administrators', teachers', students' views and quality of science projects]. Adlyaman Üniversitesi Sosyal Bilimler Enstitüsü Dergisi, 6(12), 255-308.

Ushakov, I.A. (2007). Histories of Scientific Insights. Morrisville, NC: Lulu Press.

\section{APPENDIX}

\section{Example project works}

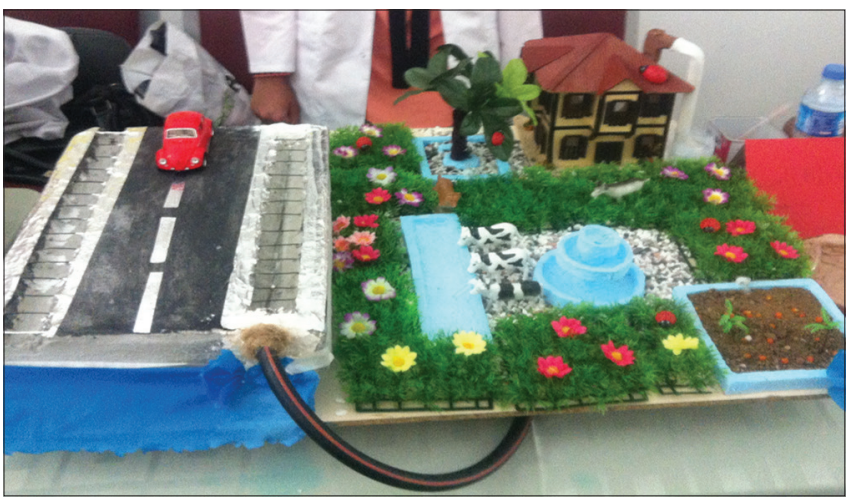

Williams, C., Stanisstreet, M., Spall, K. Boyes, E., \& Dickson, D. (2003). Why aren't secondary students interest in physics? Physics Education, 38(4), 324-329.

Yıldırım, A., \& Şimșek, H. (2008). Sosyal Bilimlerde Nitel Araștırma Yöntemleri. [Qualitative Research Methods in Social Sciences]. Ankara: Seçkin Yayınları.

Yılmaz, F.N. (2015). Fen Bilimleri Öğretiminde Proje Tabanli Öğrenme Yaklaşiminin 6. Sinif Öğrenci Başarisi ve Bilimsel Süreç Becerilerine Etkisi. [The Effect of Project-based Learning Method on the $6^{\text {th }}$ Graders' Achievement and Scientific Process Skills in Science Education]. Denizli: Yayımlanmamış Yüksek Lisans Tezi. Pamukkale Üniversitesi, Eğitim Bilimleri Enstitüsü.

Yurtluk, M. (2003). Proje Tabanl Öğrenme Yaklaşımının Matematik Dersi Öğrenme Süreci ve Öğrenci Tutumlarina Etkisi. [The Effect of the Project-based Learning Approach on the Mathematics Learning Process and Student Attitudes]. Ankara: Yayımlanmamış Yüksek Lisans Tezi. Hacettepe Üniversitesi Sosyal Bilimler Enstitüsü.

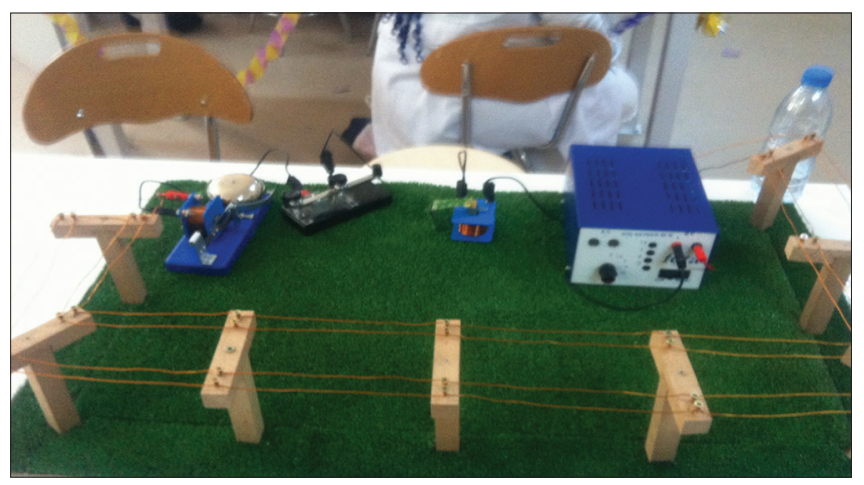

